\title{
Kanglı (Kao-Ch'e) Boyları Hakkında Bir Değerlendirme
}

\section{An Evaluation on The Kangli Tribes}

\author{
Ahmet Taşağgl ${ }^{*}$ (i)
}

"Prof. Dr., Yeditepe Üniversitesi, Fen-Edebiyat Fakültesi, Tarih Bölümü, İstanbul, Türkiye

ORCID: A.T. 0000-0002-1435-8877

Sorumlu yazar/Corresponding author: Ahmet Taşağıl,

Yeditepe Üniversitesi, Fen-Edebiyat Fakültesi, Tarih Bölümü, İstanbul, Türkiye

E-posta/E-mail: atasagil@hotmail.com

Başvuru/Submitted: 17.06 .2020 Revizyon Talebi/Revision Requested: 01.07.2020

Son Revizyon/Last Revision Received: 08.07.2020

Kabul/Accepted: 11.07 .2020

\section{Atıf/Citation:}

Tasagil, Ahmet. "Kanglı (Kao-Ch'e) Boyları Hakkında Bir Değerlendirme." Tarih Dergisi Turkish Journal of History, 71 (2020): 51-66. https://doi.org/10.26650/TurkJHist.2020.004

\section{ÖZ}

Orta Asya tarih sahnesinde boylar halinde yaşamak ve boy grupları oluşturmak önemli bir özelliktir. 7. yüzyılın 2. çeyreğine kadar üç önemli boy grubu sırasıyla Ting-ling'ler, Kanglılar ve Tölesler olarak gösterilebilir. 627 yılından sonra söz konusu küçük boy grupları daha fazla ön plana çıkarak kendi adlarıyla tanınacaklardır. Hunlar zamanında ana boy grubunun adı kaynaklarda Ting-ling'dir. M.S. 4. yüzyılda bu ana boy grubu adı kaybolarak yerini Kanglı adı almıştır. Tabgaç, Akhun ve Juan-juan gibi üç büyük siyasi gücün arasında sıkışan dolayısıyla bir devlet kuramayan Kanglılar, kaynaklarda anlatılan kültürel özellikleri sebebiyle ilginç bir yere sahiptir. Kanglılar yaklaşık 200 yıl varlıklarını koruduktan sonra Töles adıyla yollarına devam edecekler; Gök Türk Kağanlığının ana halk kitlesini meydana getireceklerdir. Daha sonra kendi özel boy adlarıyla anılarak siyasi olaylara katılan boylar aradan geçen asırlardan sonra günümüz Türk Dünyasının etnik yapısının oluşumuna katkı sağlamışlardır. Büyük hanedanlarının yanında ana boy gruplarını incelemek bir anlamda Türk tarihinin kökenlerine ışık tutmaktır.

Anahtar sözcükler: Kanglılar, Tölesler, Türk boyları, Orta Asya, Çin kaynakları, Tabgaç Devleti, Juan-juan Kağanlığı

\section{ABSTRACT}

Living in tribe formation and forming tribes are important features in the field of Middle Asian History. The Ting-lings, Kanglıs and Töleses were three important tribes up until the second quarter of the $7^{\text {th }}$ century. After 627 these little tribal groups would be more prominent and they would be mentioned with their respective names. In the time of the Huns, the main tribal group recorded in the sources was that of the Ting Lings. In $4^{\text {th }}$ century AD, this main tribe vanished and was replaced with the Kanglıs who were stuck between three great political powers, the Tabgaçs, Akhuns and Juan Juans, and were thus unable to form a state, although they have an interesting place in history due to their cultural features. After maintaining their existence for 200 years the Kanglis would became Töles and they would be the nucleus of the Gök Türk Khanate's population. Then they would be mentioned by name among the other tribes that had participated in political events, and they contributed to the formation of the ethnic structure of the modern Turkish world. Investigating the main tribe formations along with the great dynasties will shed light upon the origins of Turkish history.

Keywords: Kanglı Tribes, Central Asia, Ancient Turkic, Chinese Sources, Wei Dynasty 
İslam Öncesi Türk tarihinde 7. yüzyılın ilk çeyreğine kadar kurulan büyük devletlerin yanında üç ana boy grubu Orta Asya' da tarih sahnesinde yer almış ve daha sonra ortaya çıkacak Türk boylarına alt yapı oluşturmuşlardır. Bunlar Ting-ling’ler, Kanglılar ve Töleslerdir. 627 yılından sonra söz konusu küçük boy grupları daha fazla ön plana çıkarak kendi adlarıyla tanınacaklardır. Hunlar zamanında ana boy grubunun adı kaynaklarda Ting-ling'dir. M.S. 4. yüzyılda bu ana boy grubu adı kaybolarak yerini Kanglı adı almıştır. Tabgaç, Akhun ve Juanjuan gibi üç büyük siyasi gücün arasında sıkışan dolayısıyla bir devlet kuramayan Kanglılar, kaynaklarda anlatılan kültürel özellikleri sebebiyle ilginç bir yere sahiptir. Kanglılar yaklaşık 200 yıl varlıklarını koruduktan sonra Töles adıyla yollarına devam edecekler; Gök Türk Kağanlığının ana halk kitlesini meydana getireceklerdir. Kaynakların verdiği bilgiler ölçüsünde Kanglı (Kao-ch'e)'ların kültürel ve siyasi durumu değerlendirilecektir.

Ağırlıklı olarak Kazakistan bozkırları olmak üzere geniş alanlara yayılmış Ting-ling丁零 boyları adı birden kaybolur ve yerini Kanglı (Kao-ch'e/高車) boy grup adı alır. Yüksek Araba anlamına gelen Kanglı (Kao-ch'e/高車 okunuşu Gao-çı), teriminin Türkçe karşılı̆̆ı Kanglı olmalıdır. En azından Türkçe tercümesi budur. Biz daha önce yazdığımızın (Kao-ch'e) ${ }^{1}$ aksine daha anlaşılabilir olması için Türk kültüründeki karşılığı Kangılı (Kağnılı) sözüyle yazdık. Yani burada kullandığımız Kanglı adı Çince kaynaklarda geçen Kao-ch'e/高車 teriminin Türkçe karşılığıdır. Konunun daha iyi anlaşılması için bu yol tercih edilmiştir.

7. yüzyıl ortalarında yazılan Çin kaynakları Kanglıların köklerini Hunların ataları zamanında aramışlar ve o dönemde geçen Kızıl赤狄 veAk Ti 狄白 (okunuşu Di) topluluklarıyla aynileştirmişlerdir. Böyle bir bağlantı kurma Kanglıların öncesinde Ting-ling'lerin bağımsız ve geniş coğrafyaya yayılma durumundan kaynaklanmaktadır. Bunun yanında Ak ve Kızıl Ti kavramlarının içinde de Kızıl Ti grubuna bağlanması ${ }^{2}$, işaret edilen genel boy kitlelerinin güneyinde bulunduğunu gösterir. Fakat, durumun açık olduğunu söylemek mümkün değildir. Ancak, Kanglıların doğrudan Ting-ling'lerin devamı olduğu açıktır. Daha doğrusu sadece Ting-ling adı tarih sahnesinden kaybolmuş; yerine Kanglı adı kullanılmaya başlamıştır. Her şeyden önce bu tür adlandırmaların komşu milletler tarafından yapıldığını göz önüne almak gerekir. Sonuçta biz o devirde Kanglıların kendilerine ne dediğini bilmiyoruz. Yüksek Araba kavramı kendilerinin imal ettikleri ve kullandıkları büyük tekerleklerden kaynaklanmaktadır. Komşularına göre farklı daha yüksek tekerlekli arabalar ürettikleri ve bu arabalara bindikleri veya yük taşımacılığında kullandıkları bilinen bir gerçektir.

Çin kaynakları Kanglıların (Kanglı)'ların kökenini, efsanevî devirlere kadar götürür. Bu söz konusu kaynakların genel bozkır boy dağılımı açısından geleneksel bir yaklaşımıdır. Ön plana çıkan ve önemli roller oynayan toplulukların ataları çok eski devirlerde aranır.

1 Ahmet Taşağıl, Çin Kaynaklarına Göre Türk Boyları, Ankara 2004, s. 28-41; Kao-ch'e'lar için ayrıca bkz. Bahaeddin Ögel, “İlk Töles Boyları”, Belleten, XII/48 (1948), 795-833.

2 Pei Shih北史 98, s. 3270; Wei Shu魏書 103, 2307. 
Hunların atalarının anlatıldığg dönemde söz konusu edilen çok sık adları geçen Ti’lerin ${ }^{3}$ Kızıl Ti grubunun onların ataları olduğuna işaret edilir ${ }^{4}$. Daha sonraları Ti-li adıyla anılmışlar ve bundan dolayı pek çok araştırıcı tarafından Ting-ling boylarının devamı olarak değerlendirilmişlerdir ${ }^{5}$. Çinlilerle temasa geçmeden önce kuzeyde yaşarlarken adları Ch'ih-lo idi ${ }^{6}$. Eğer bu boyun daha önce varlığını tesbit edebilsek farklı sonuçlara ulaşmamız mümkün olacaktı. Yine kaynakların bildirdiğine göre onların atası Hunların (hükümdarının) yeğeni gösterilir. Bu durum da aklımıza "acaba Kanglı boy liderleri Büyük Hun Imparatorluğu hanedan ailesinden mi geliyorlardı?” sorusunu getirmektedir. Dilleri Hunların konuştuğu dil ile aynı olup sadece arada küçük bazı farklar vardıํ. Biz bu tür bir değerlendirmeyi Doğu Gök Türk - Batı Gök Türk dillerinin anlatılmasında da görürüz. Diğer taraftan AkhunEftalitlerin Kanglılarla ilişkisi ve kökeni konusundaki ilgileri oluşları Japon alimi Kazuo Enoki tarafindan ileri sürülüp tartışılmıştır ${ }^{8}$.

Kanglıların sosyal hayatı ve gelenekleri hakkında ilginç bilgiler kaynaklara yansımıştır. Bunlar Hunların ataları zamanında başlayan ve bizim ilk izlerine rastlayabildiğimiz bozkır sosyal hayatının devamı niteliğindedir. Onların kültürü hakkında şöyle bir değerlendirme yapılmıştır: Onların bir hükümdarı yoktu kaydından onların devlet kuracak kadar üst düzey bir örgütlenme yapamadıkları sonucunu çıkarırız. At ve sığır düğ̈̈n hediyesi daha doğrusu çeyiz olarak kızla birlikte damat tarafina verilirdi. Bu bilgiden doğrudan kızların mirastan pay hakkı konusuna açıklama getirilir. Bu vergi de olabilir kaydından vergi olarak geleneksel koyun vergisi aklımıza gelir. Düğünlerinde çiğ et yedirilir ve kısrak kımızı içirilirdi. Bilindiği gibi kımız geleneksel içkidir. Çiğ et konusunda Çinliler kadar pişirmedikleri konusunu anlarız. Temiz değillerdir. Bu konu da Çinlilere göre daha az yıkandıkları sonucunu ortaya koyar. Çünkü onlar bozkırlarda yaşıyorlardı. Kadınlar koyun kemiklerini deriye sararlar ve bunu saçlarına dolandırarak başs süsü diye taşırlar. Söz konusu ifade de koyun kemiklerinden saç tokası yaptıklarına işaret eder. Ölüler silahları ile birlikte mezara konulur. Gök Türkler zamanındaki geleneklere uygun olarak defnedilirdi sonucu çıkar. Kültürleri Juan-juan 'larınki gibidir. Kanglıların zamanında büyük devlet Juan-juan'lardır. Dolayısıyla model olarak onu alan Çin kaynakları daha sonra Gök Türkleri esas alarak boyları değerlendirecektir. Sonuçta bozkırları paylaşarak hayatını idame ettiren halklardır. Dolayısıyla kültürlerinin benzemesi de normal bir durumdur. Yalnız arabalarının tekerleği daha büyüktür. Bu ifade doğrudan Kanglı meselesine açıklık getirir. Onların kullandıkları arabaların diğerlerine

3 E. Esin, İslâmiyetten Önce Türk Kültür Tarihi, İstanbul 1978, s. 49-52; C. Türkeli, Çin Kaynaklarına Göre Hunların Ataları, İstanbul Üniversitesi Sosyal Bilimler Enstitüsü, Yayınlanmamış Doktora Tezi, İstanbul 1991, s. 15 vd.; K. Salgarulı, Dunhu-Kaoçı, Almatı 1999, s. 78-82.

4 Pei Shih 98, s. 3270; Wei Shu 103, 2307.

5 A. Taşağıl, Çin Kaynaklarına Göre Türk Boyları, Ankara 2004, s. 7-12.

6 Pei Shih 98, s. 3270; Wei Shih 103, 2307.

7 Taşağıl, s. $28 \mathrm{vd}$.

8 K. Enoki, "On the Nationality of the Ephtalites", Studia Asiatica, Tokyo 1998, s. 140-143. 
göre daha yüksek olduğunu açıklar. Mitolojilerinde kurttan hamile kalma vardır. Bu yüzden şarkıları kurt ulumalarına benzer imiş. Bu durum doğrudan Türk kökenli bir bozkır boy grubu olduklarını açıklar. Daha sonra Gök Türklerin kuruluşunda daha gelişmiş bir mitolojik metin detay görürüz. Bütün Türk kökenli toplulukların sosyo-kültürel iz ve özüne burada rastlamamız çok önemli bir noktadır. Çadırlarda oturup, at beslerler ${ }^{9}$. Kadın kamları da mevcuttur. Her iki konuda Eski Türk sosyal hayatı konusunda bize 1şık tutar.

429 yılından sonra Kanglı boylarının çoğunun göçebeliği terk edip tarla ziraatine geçtikleri bildirilir. Geleneksel hayat tarzını değiştiren boyların nerelerde yaşadığı açıkça belirtilmese de Turfan civarında olduklarını tahmin ediyoruz. Çünkü daha sonra Töles boylarını anlatan metinlerde ${ }^{10}$ Turfan'a yakın yerlerdeki boyların bitki yetiştiriciliğinde uzmanlaştıklarına dair bilgiler vardır. 450 yılındaki büyük törende ise beş grup bir araya toplanmış ve göğe kurban sunmuşlard $\imath^{11}$. Genel dağınık olduğunu ifade ettiğimiz boyların senenin belirli zamanlarında bir araya gelerek tören yapmaları ilginç bir durumdur. Haziran ayının 10-20. günleri arası bahar bayramı niteliğinde törenler yapılıyor ve kurbanlar sunuluyordu. Aralarında herhangi bir siyasi birlik bulunmayan insan gruplarının sosyal ve kültürel hayatta bir araya gelerek hayat tarzlarını sürdürmeleri varlıklarını korumaları açısından bütünlük arz etmektedir.

Rivayete göre (onların söylediğine göre): Hun hükümdarının çok güzel iki kızı vardl. Onlara kutsal olduklarl gözle bakılıyordu. Hükümdar "Ben bu kıları normal herhangi bir insana veremem, onlarl Göğe (Tanrl) vereceğim” dedi. Bu sebepten merkezinin dışındaki insan ayă̆ının basmadı̆̆ bir yere kule gibi bir bina yaptırıp "Göğün kendisi gelip alsın” diye dilekte bulunarak iki kızını oraya yerleştirdi.

Aradan üç yıl geçtiğinde kızların anası onları geri getirmek istedi. Hükümdar "olmaz, hala vakti gelmedi" dedi.

Bundan sonra daha bir yıl geçtikten sonra, yaşlı bir kurt gelip kule-evin altına in kazdı ve gece gündüz uludu. Bunu gören küçük kız: Bizi babamı, Gök'e vermek için buraya yerleştirdi. Şimdi buraya bir kurt geldi. Belki onun gelişi bir iyiliğin işareti olmalıdır" diyerek evden çıkıp kurdun yanına gitmek istedi. Ablası "bu hayvan, ona varıp, ata-anamızı küçük düşürme” diye karşı çıktı. Onu dinlemeyen kız kardeşi kurda vardı. Onunla evlenip bir oğlan doğurdu. Bu oğuldan gelen torunlar çoğalarak kendilerine bir devlet kurdular. Bu sebepten onların insanları uluyan kurt gibi konuşurlar.

Onların yaşayışı hakkında devam ederek: Onların bir merkeze bağlı liderleri yoktur. Her kabilenin kendi idarecisi yani boy beyi vardır. Birbirleri ile dayanışma içinde yaşarlar. Akın

9 Pei Shih 98.

10 Pei Shih北史 99; Suei Shu 隋書85; T'ung Tien 通典199-1080; Wen-Hsien T'ung-k'ao文獻通考 344-2698 a, b; Ts'e-fu Yüan-kuei冊府元龜 956, 33, 34; Chiou T'ang Shu 舊唐書199, s. 5343-5345.

11 Wei Shu 103. 
vaktinde, tehlike anında birbirleri için canlarını verirler. Çarpışmalar esnasında bir hatta durmazlar, üç kola ayrılıp düşmanlarını sıkıştırırlar. Aniden saldırıp aniden geri çekilirler. Belirli bir yerde savaşmazlar. Evlenme sırasında at ve öküz verilmesinin büyük önemi vardır. Anlaştıktan sonra dünürlük kurulur. Damadın akrabaları atları sürerek getirirler ve kızın akrabalarının her biri istedikleri atı kendileri tutup alırlar. Atların sahipleri çevrilen yerin dışına çıkarak ellerini şaklatırlar ve atları ürkütürlerdi. Atlardan düşmeyenler, bindikleri atlart alırlar. Düssenler ise yeniden at seçer. Dünürler atları seçtikten sonra dügün töreni sona ererdi. Tahıl yetiştirmezler, şarap yapmazlardı. Düğ̈̈n günü damat ve geline kımız ile kurutulmuş et verilir. Ev sahibi konukları bekler. Yerlere oturmada düzen yoktur. Yurt keçe evin önüne grupla gelip çimenlerin üzerine oturur, uzun gün boyu et yiyip, kımız içerler. Geceye de sarkıtırlardı. Ertesi günü gelinlik kız kendi babasına varıp, damadın akrabaları atları dönerek kızın evine sürüp getirirler. Gelinin akrabaları daha da onların içinden atları seçip alırlar. Kızın ana-babası ve kardeşleri ve yakın akrabaları hiçbir şey demezler. Dul kadınlara evlenmeyi münasip görürler. Öylelerine saygl gösterirler. Dışarıda yürüyüşs sırasında yabancı adamla karşılaşı̆ı̆ında onu hiç kimsenin almadığına bakarak hayvanlarına damga basarlar. Ev içinde temizliğe dikkat etmezler. Yıldırım düşmesi hoşlarına gider. Her yıldırım düşüşünde göğe ok atarlar. Bundan sonra o yeri bırakıp başka bir yere giderler Ertesi yıl sonbaharda atlar semizleştiğinde, yıldırım düssen geçen yılki yerde toplanıp koyun keserler bıçakla yüzüp meşale (kandil) yaparlar, aynı felaketi Çin'deki yakma gibi kadın kam dua eder. Ata binen erkekler grubu yıldırım düssen yerin etrafinı dönerler. Üyenki (bir ăgaç cinsi) veya karağacın dallarından bir demet alıp kesilen yerlerini yukarı doğru koyarlar, onun üstüne kımız koyarlar. Kadınlar koyun kemiğini kendi başlarına koyarlar, saçlarını çevirerek büklüm yapıp uçlarını aşağıya salarlar, böylece taç gibi görünür.

Ölüyü kazllan yere götürüp, cenazeyi onun içine koyarlar, eline çekilmiş ok tuttururlar, beline kılıç takarlar, aynı canlı adammış gibi koltuğunu mızrak sıkıştırırlar, mezarı gömmezler. Ĕ̆er biri yıldırım düşüp ölse veya hastalıktan ölse, ona baht için dua edilir. Ĕger hepsi iyi sonuçlanmışsa o zaman ruhlara ulaştırıp bildirmek için her türlü hayvan kesip, kemiğini ateşte yakıp gönderirler. Bundan sonra yeri ata binip döneler. Bazen birkaç yüz kez dönerler. Buna herkese katılır. Evinde her şeyi iyi să̆ salim olanlar şarkı söyleyip, müzik eşliğinde oyun oynarlar. Evinde biri ölenler üzüntüden ă̆layıp, göz yaşı dökerler ${ }^{12}$.

Onlar bir yerden bir yere otun bol, suyun gür olan yerine göçüp giderler. Deriden giysiler giyerler, etli çörek yerler. Hayvanları Juan-juan'larla aynıdır. Sadece arabalarının tekerlekleri yüksek ve bağlantı yerleri çoktur ${ }^{13}$.

Kanglılar, kuzey doğularında Juan-juan'lar, güney doğularında Tabgaç Devleti ve güney batılarında Akhunlar tarafından çevrelenmişti. Dolayısıyla tarihleri o zamanın bu büyük üç

12 Bu konuda ayrica bkz. Bahaeddin Ögel, Türk Mitolojisi, Ankara 1993, s. 17-18.

13 Pei Shih 98. 
gücü arasında varlığını devam ettirebilme mücadelesi şeklinde gelişecektir. Anlaşıldığına göre mühim ve kalabalık kütleleri Turfan civarında oturuyor, duruma göre Juan-juan ve Tabgaç Devletleri arasında bağlılık konusunda tercih ediliyorlardı.

Sosyal hayatları ve kültürel durumları hakkında bu değerlendirmeleri yaptıktan sonra şimdi tarihi kaynaklarda verilen bilgiler ışığında Kanglıların siyasi tarihine devam edelim. M.S. I. yüzyılın sonlarına doğru bölünmüş Hunlar, hızla yıkılışa giderken doğudan gelen Hsien-pi'ler güçlenerek onların yerini almaya başladılar. Özellikle M.S. 89' da Hunlara karşı aldıkları galibiyet Moğolistan ve Kuzey Çin'de onları en büyük güç haline getirdi. Aynı sıralarda bağımsız kalan Kanglılar henüz Ting-ling adını taşıyorlardı. Doğuda yükselen yeni güç Hsien-pi Devletine bağlandılar. Fakat, Kanglı boylarının tamamının onların hakimiyetine girdiği söylenemez. Sadece Gobi Çölünün güney ve kuzeyinde yaşayan Kanglı grupları Hsien-pi'lere katılmış olabilir. Bu arada söz konusu Kanglı boylarının avcılık ve hayvancılık ile geçindikleri ve aralarında herhangi bir siyasi birliğin bulunmadığının bildirilmesi ilginçtir. Dolayısıyla aralarında bir siyasi örgütlenme gerçekleştiremedikleri için dağınık vaziyette yaşıyorlardı. Aksine Hsien-pi’lerin kurduğu Juan-juan Devleti ise kısa sürede büyümüştü. Güneybatılarında bulunan Kanglıların onlara direnecek gücü yoktu. Zaten onlar da direnmeyerek bağlandılar.

Neticede Ting-ling'ler yani Kanglılar (Yüksek Arabalılar/Kao-ch'e) da adı geçen kavmin hakimiyetini tanımak zorunda kalmışlardı. Bu esnada Kanglıların bir kısmı, Gobi Çölünün güneyi ve kuzeyinde avcılık ve hayvancılıkla iştigal ediyorlardı ve herhangi bir devletleri yoktu. Akabinde Juan-juan Devleti, tesis edildikten hemen sonra hızla büyümüştü ${ }^{14}$. $\mathrm{Bu}$ devlet 5. yüzyılın başında güney batılarındaki Kanglı bölgesini ele geçirdi. Onlara direnemeyerek yenilgiye uğrayan Kanglıların lideri Pei-hu-li, Çin’deki Tabgaç (Kuzey Wei) Devletine kaçarak kendini kurtarabildi. Hizmetine girdiği Tabgaç hükümdarı Tao-wuti, ona kötü davranmadığı gibi kendi devleti içerisinde yüksek bir makam vererek koruması altına aldı. Tabgaçlar ile Juan-juan'lar rakip oldukları için hükümdarın işine geliyordu. Ayrıca Juan-juan hükümdarının onun öldürülmesi konusunda baskı yapması söz konusu olamazdı. Tabgaç Devleti hizmetinde çok başarılı olan Pei-hu-li'nin torunları Kuzey Wei (535-557), Doğu Wei (550-577) ve Kuzey Ch'i devrine kadar üst düzey görevlerini devam ettirdiler.

Cungarya, Tarbagatay ve Tanrı Dağlarının doğu taraflarında yaşayan Kanglılar ise Tabgaçlara rakip olmuşlardı. Dağınık durumda olmaları ve kendi aralarındaki organizasyonsuzluk burada da kendini gösterdi. Defalarca savaşmalarına rağmen Tabgaçlar karşısında galip gelemediler. 300'lü yılların sonlarında birkaç defa Tabgaçlar tarafından mağlup edilen Kanglı'lar, esas ilk ağır yenilgilerini 389 yılında almışlardı. On iki yıl sonra

14 Çin'deki Tabgaçlar ve Juan-juan ilişkileri için bkz. Fan Kuo-chien, Pei Wei Yü Juan-juan Yen-chiou, Tai-pei 1988. 
Tabgaçlar bir kez daha onları yendi ve yirmi binden fazla araba ele geçirdiler. Bu savaşlar sırasında onların kabile sayısının otuz yedi olduğu bildirilmektedir. Bundan iki yıl sonra bir kabile daha teslim oldu ${ }^{15}$.

Aslında nüfus ve boy sayısı bakımından hatırı sayılır güçleri vardı. Ama bir türlü kendilerinden daha organize kuvvetlerle baş edemiyorlardı. Sonuçta asla birleşemediler ve aralarında bir devlet kuramadılar. Kanglıların doğu grubu Juan-juan'lar ile Tabgaçlar arasında hakimiyet konusunda sürekli el değiştirdiler. Onların bu başarısız teşkilatlanma halleri, neticede Tabgaçlar ile Juan-juan'lar arasında gidip gelmelerine yol açtı.

Bazı Kanglı boylarının güçlenerek ön plana çıkmaya gayret ettiğini ancak bunu uzun zaman sürdüremediğini görüyoruz. Bu Kanglı boyları arasında diğer boylara nazaran daha fazla yükselerek idareyi elinde tutan Ho-lui kabilesi gücünü yitirince Moğolistan'da bulunup biraz canlanmış olan Kanglı siyasi birliği dağılıp gitti. Bundan sonra onlar Juanjuan'lara göçüp bağlandılar. Kuzey Wei Devletinin hükümdarı T'ai-wu, Juan-juan'lara üç kez sefer düzenlemek zorunda kalmıştır. Söz konusu askeri seferlerin en büyüğü 429 yılında gerçekleşmiş, Nisan ayından Temmuza kadar devam etmişti. Neticede Juan-juan'lar ağır yenilgiye uğrayınca onların idaresi altındaki Kanglı kabileleri kendi bağımsızlıkları için hareketlenmeye başladılar.

Kanglıların doğu grubu yaklaşık “Kingan Dağlarından Kuzey Moğolistan 'a” kadar geniş sahada yaşayanlar Kuzey Wei Devletine itaat ettiler. Bununla beraber Kanglı boylarının tamamen Tabgaçlara bağlandığını söyleyemeyiz. Mesela Kuzey Moğolistan'daki Fu-fu-lo adlı Kanglı kabilesi ile birlikte başka bazı boylar batıya doğru harekete geçtiler. 481 yılına gelindiğinde batıya gidenlerin Tanrı Dağlarının güney doğu eteklerine ve özellikle Turfan/ Beşbalık (Kao-ch'ang)'a yerleştiğini görüyoruz. Turfan bölgesindeki küçük devletçik onlar tarafından ele geçirilmişti. Bundan sonra onların yeni yerleştikleri bölgede kuvvetlendiklerine şahit oluyoruz. Nitekim, 485-486 yıllarında A-fu-chih-lo liderliğindeki Fu-fu-lo kabilesi, Altay, Tanrı dağlarının arasındaki sahada uzun mücadeleler yaptıktan sonra Cungarya'da bağımsız bir devlet kurmayı başardı.

Aradan çok zaman geçmeden batıda yönünde bir düşmanla karşılaştılar. O sırada gücünü zirvesinde olan Akhunlar, Cungarya'daki Kanglı Devletinin uzun süre yaşamasına izin vermediler. Onların saldırısı sonucu Kanglı Devleti yıkıldı ve arta kalanlar, doğuya yönelerek Juan-juan'lara boyun eğmek zorunda kaldılar.

Burada bahsettiğimiz olaylarda yer alan Kanglıların çok sayıda boydan meydana geldiği anlaşılmaktadır. Ancak aşağıda görüleceği üzere bu boylardan bazıları diğerlerine nazaran daha örgütlü oldukları için güçlenmişlerdi. Dolayısıyla ön plana çıkmaları mümkün oluyordu.

15 Wei Shu 2. 
Bu olaylar esnasında temayüz eden önemli kabilelerin adlarının Ti, Yüan-ho, Hu-lü, Chie-pi, $H u-k u, \dot{I}$-ch 'i-chih olduğunu anliyoruz ${ }^{16}$.

Bunlardan çoğu Lu-hun (Lukçun) Denizinin (göl) kuzey batısına 100 li'den fazla mesafede olan bir sahaya göç ettiler. Bu bölgede Çin ile daha yakından ilişki kurmak imkanı bulacaklardı. Burada sayıları artıp kuvvetlendiler. Juan-juan'larla düşman oldular. Ayrıca sürekli Wei ülkesine saldırıda bulundular ${ }^{17}$. Söz konusu bölge Kao-ch'ang yani Turfan'dır.

\section{Gobi Çölü ve Batısındaki Kanglılar}

Kansu eyaletindan başlayarak Kuzeybatı Çin'de hakim olan Tabgaçlar, daha sonra hakimiyet alanlarını Orta Çin'e doğru genişletti. Hatta daha da doğuya doğru uzandı. Her ne kadar Çin'in zengin topraklarına sahip olsalar da Tabgaç yöneticilerinin bozkırda gözü vardı. Bunun için rakipleri Juan-juan'larla çetin mücadelelere giriştiler. Kanglılar da böylece iki güç arasında sıkışmışlardı. Onlar duruma göre hareket ediyorlar, bazen Tabgaçlara bazen Juan-juan'lara bağlanıyorlardı. Ancak Tabgaçlar Kanglıları ve bölgelerini kendi hakimiyetine almaya karar verdi. Bunun için çeşitli zamanlarda Cungarya bozkırları, Tarbagatay ve Batı Moğolistan topraklarına uzanan seferler düzenledi. Tabgaç hükümdarı T'ai-tsu (Wei İmparatoru T'ai-wu M.S. 424-452) onlar üzerine hücuma kalkan ilk imparatordur. İmparatorun onlar üzerine bizzat büyük bir ordu ile uzun bir süren sefere çıkması Kanglıların o devirde hatırı sayılır derecede kuvvetli seviyede olduklarına işaret eder. İlk seferinde Tabgaç imparatoru Jo-lo Suyu'nu geçerek, batıya doğru Lu-hun Denizine kadar ilerlemiştir. Orada bindiği savaş arabasını bırakıp bölgenin coğrafi şartlarına uygun şekilde ata binerek kuzey batı istikametinde yüz li'den fazla ilerledi. Kanglıların beklemediği ani bir baskın düzenleyerek onları ağır bir yenilgiye uğrattı. At, sığır ve keçi gibi hayvanlardan iki yüz binden fazla ele geçirilmiş, ayrıca çok sayıda insan esir alınmıştı. Onun baskınından kurtulabilenleri de takip ederek Kurt Dağı (Lang Shan)'nda bir büyük bir galibiyet kazandı.

Arkasından kuzey bölgelerini tamamen teftiş etmek maksadıyla generallerini doğu batı olmak üzere ikiye ayırıp kendisi altı ordu ile orta yoldan ilerledi. Neticede Chiao-jan Suyu'nun kuzey batısında yaşayan Kanglı kabilelerini de bozguna uğratıp liderlerini yakaladı. Düzenlenen büyük askeri seferde bütün Tabgaç ordularının birleşmesi sayesinde ayrı ayrı askeri birimlerden oluşan Kanglıların otuzdan fazla boyunu yenmişlerdi. Bundan başka Prens İ, kuzey batıya doğru hücuma kalkıp Gobi Çölü'nün içinde yüz li (50 km) daha ilerledi. Geride kalıp kendini kurtarmış yedi kabileyi daha mağlup etti. Tabgaç hükümdarından arka arkaya ardına kuvvetli darbelere maruz kalan Kanglılar korkup dağılmışlardı. Demek ki, tamamen yok edilmemiş ya da itaat altına alınmamışlardı. Ayrıca daha sonra imparatorun Niou Ch'uan (dere)'ın güneyine çekilip bir av düzenlediğinde yedi yüz li' lik bir alanı çevirme

16 Wei Shu 103, s. 2307; Pei Shih 98, s. 3270.

17 Wei Shu 103, s. 2308; Pei Shih 98, s. 3271. 
görevini Kanglı atlılarına vermesi önemli bir süvari gücünün Tabgaçların askeri kuvvetleri arasında yer aldığını gösterir. Atlıların olağanüstü çevik hareketi sonucunda çok sayıda av hayvanı P'ing-ch'eng'a sürülerek, Çinliler tarafından kolayca avlandı. Onların bu başarılı işinden dolayı Tabgaç imparatoru Kanglılar için bir geyik bahçesi yaptırttı kaydını belirli bir alanın Kanglı boylarının avlanması için tahsis edildiği şeklinde değerlendirmek gerekir. Söz konusu bu bahçe (av sahası) güneyde T'ai-yin'i takip ederek, kuzeyde Çin Seddi'nden biraz uzakta, doğuda Pai-teng'ı içine alıp Batı Dağlarına kadar gidiyordu ${ }^{18}$.

Tabgaçlar ele geçirdikleri Kanglı boyları mensuplarını doğrudan asimile etmek istemediler. Onların Çinlileşmesi işlerine gelmezdi. Çünkü, kuzeyin dinamik insanları iyi savaşçı süvarilerden meydana geliyordu ve Çinlilerin daha fazla işlerine yarardı. Böylece daha sonra Gök Türklerin Çin'e yerleştirilmeleri sırasında açık misallerini görebileceğimiz bir uygulama yapıldığı anlaşılıyor. İşin özünde Çinlilere yenilen ya da teslim olan boylar bu ülkenin sınırları içinde kuzey taraflarında kendi hayat tarzlarını devam ettirebilmeleri maksadıyla yerleştiriliyordu değerlendirmesini yapabiliriz.

Hunların zayıflayıp kıtlık içine düştükleri zamanda gerçekleştiği gibi bozkırın insanları daha rahat yaşamak ve yiyecek bulmak amacıyla kitleler halinde göç ettiği olay tekrarlanıyordu. Kanglı boyları da akın akın giderek Çin’e sığınması dengeleri değiştiriyordu. Nitekim, Çin’e teslim olan Kanglı boylarının sayısı bununla da kalmamıştı. Chih-li-ho, Mo-fu Ts'u-li-chien gibi reisler de dokuz yüzden fazla aile ile birlikte Çin tabiiyetine girdiler. Bunlardan Ts'uli-chien'e Çin generallik ve bazı askeri unvanları takdim edildi. Chieh-pi boyu, reisleri Mofu Fan-tou-chien kendi kabilelerinden otuzdan fazla birlik ile Çinlilere tâbi olmuştu. Onu devlet hizmetinde bir göreve atadılar. Savaş bakanı yardımcısı Ssu-ma Tsan-chün (?) gibi yüksek bir makama tayin edildi. Ayrıca kendilerine imparator tarafından maaş ve yiyecek de bağışlanmıştı. Yukarıda şahıs isimlerinde geçen Mo-fu adının Türkçe Baga olduğu anlaşılır ${ }^{19}$.

Ardı ardına üzerlerine düzenlenen seferlere dayanamayan Kanglılar, zaferler kazanamasalar da tamamen yok olmadılar. Bunlardan biri Chie-pi boyu idi. Chie-pi boyundan sonra bir başka Kanglı kabilesi ön plana çıkmaktadır ki, onun adı da Hu-lü’’dür. Moğolistan coğrafyasında hakim olan Juan-juan'ların hükümdarı She-lun, Tabgaçlar tarafından mağlup edilince askerlerini toplamış ve Gobi Çölünün kuzeyine çekilmişti. Bu sırada Kanglıların Hu-lü boyunun reisi Pei-ho-li, onun düştüğü zor durumdan memnun olarak şöyle demişti: "She-lun'un yeniden topladĭ̆ askerler aciz ve atlarl da azdır. Onun işine bakmak şimdi kolaydır".

Bundan sonra kendi boyunun insanlarını toplayan Pei-ho-li gizlice onların memleketine girdi. İlk önce kolayca zafer elde ettikten sonra hemen rehavete kapıldılar. Ama arkasından

18 Wei Shu 103, s. 2308; Pei Shih 98, s. 3271-2372.

19 Wei Shu aynı yer; Pei Shih aynı yer. 
başlarına büyük bir felaket gelecekti. Juan-juan'ların çadırlarını ve evlerini yıktıkları gibi kadınları ve kızlarını alarak uykuya daldılar. Onların bu gafletini uzaktan yüksekten gören She-lun, kaçan dağılan halkını topladı. Nihayetinde, bin kişi toplamayı başararak sabahı bekledi. Erken vakitte düzenlediği bir baskınla hepsini katletti. Ani baskından Hu-lü boyunun sadece onda ikisi-üçü kurtulabilmişti. Kurtulmayı başaran, ancak, her şeyini kaybederek yalnız kalan liderleri Pei-ho-li gidip Tabgaçların hizmetine girdi ve kendisine Meng-tu düklüğ $\ddot{u}^{20}$ unvanı sunuldu.

Bundan sonraki süreçte Pei-ho-li, Çin'de çok meşhur olmuştur. Özellikle onun kahraman, dürüst insan karakteri gösterdiğinden bahsedildiği gibi savaş atlarına bindiğinde diğer bütün insanlardan farklı bir görüntü çizdiği vurgulanmıştı. Onun heybeti ve haşmetinden dolayı ağlayan çocukları korkutmak için "Pei-ho-li geliyor" diye söyleyip korkutarak sustururlarmış. Diğer taraftan bekar kızlar "iyi bir koca arıyorsanız, aradığınız Pei-ho-li gibi olsun” derlermiş. Üstelik saadet ve felaketin gelip gelmeyeceğini bildiği ve "elli fal çubuğunu” çok iyi kullandığı ifade edilmiştir. Dolayısıyla Çin sarayında çok itibar kazanan Pei-ho-li'nin küçük oğlu Ho-tang'ın da saray hizmetine girmesine izin verildi. Onun ölümüne çok üzülen Tabgaç imparatoru cenazesinin Çin usullerine göre defnedilmesini ve ölüm sonrası unvanının Ch’ung-chuang (sadık ve kuvvetli) olmasını emretti²1.

Onun Orta Asya sahnesinden çekilip Tabgaçlara sığınması üzerine ortaya çıkan boşlukta, Yüan-ho adlı kabile daha sonra Orta Asya'nın doğusunda ön plana çıkmaktadır. Kanglıların bu boyunun Uygurların 5. yüzyıldaki ataları olduğu iddia edilmiştí2 ${ }^{22}$ On iki Kanglı boyunun adları arasında zikredilmeyen Yüan-ho boyunun adı sadece General İ-wei'in seferi sırasında geçmekte ve Wu-pin boyu ile birlikte bahsedilmektedir ${ }^{23}$. Adı geçen general yirmi bin kişi ile kuzeyde sefere çıkmış ve Kanglı boylarından Yüan-ho'lar ile Wu-pin'leri mağlup etmişti.

Yukarıda adından bahsettiğimiz Hu-lü boyunun reisi Pei-ho-li öldükten sonra Çinli kumandan İ-wei, yirmi bin kişilik bir süvari kuvvetiyle kuzeye doğru harekete geçti. Karşısına çıkan Kanglı boylarından Yüan-ho ile Wu-pin'leri mağlup etti. Tao-wu zamanında Kanglı'ların Çinlilere göre çok farklı vahşi karakterde oldukları için adı geçen kumandan ele geçirdiği kabileleri çeşitli yerlere dağıtıp yeni kabileler meydana getirilmişti²4.

20 Dük (kung) batı dillerindeki karşılığıdır. Türkler de Dük (kung) unvanı yoktur. Ancak belki ayanlık gibi düşünülebilir. Burada Çin'de bu unvanı aldığı için açıklamasına gerek görülmemiştir.

21 Pei Shih 98, s. 3272; Wei Shih 103, s. 2309.

22 Ögel, a.g.m., s. 818.

23 Wei Shu 103, aynı yer; Pei Shih 98, aynı yer.

24 Wei Shu aynı yer; Pei Shih, aynı yer. 


\section{Kanglıların Juan-juan'larla İlişkisi}

M.S. 413 yılından sonra Juan-juan'ların Kanglı boylarıyla kurdukları münasebetlerden kaynaklar bahsetmektedir. Bu tarihten önce Kanglıların Ch'ih-lo-hou isimli beyi, bağlı olduğu kendi reisine isyan edip Juan-juan'ların hükümdarı She-lun'a sığındı. Ona yol göstererek Kanglılara hücum ettirdi. Yine Kanglılar yenilerek dağıldılar ve onların reisleri Ch'ih-lo-hou oldu. Buna rağmen Juan-juan'lar arasında Ch'ih-lo-hou mutlu olamadı. Çünkü, She-lun'un oğlu She-pa ile Pu-lu-chen onun evine gidip küçük karısı ile münasebette bulundular. Kadın, Pu-lu-chen'a kocasının Ta-tan adındaki prensi tahta çıkarmak istediğini ve bu yüzden Tatan'ın altından at dizginini güven telkin etmek için gönderdiğini söyledi. Bunu duyunca çok kızan Pu-lu-chen, sekiz bin süvari ile Ch'ih-lo-hou'yu kuşattı. Çaresiz kalan Ch'ih-lo-hou bütün eşyasını yaktıktan sonra kendisini bıçakla öldürerek intihar etti. Arkasından Ta-tan'a da gizlice bir tuzak kuran Pu-lu-chen onu da ortadan kaldırmak niyetinde idi. Ancak, vaktinde hareket eden Ta-tan, Pu-lu-chen ve She-pa'yı yakalatıp, iple boğdurttu kendisi tahta çıktı ${ }^{25}$.

Kanglı'ların başsız oldukları için, kendilerine sığınacak bir devlet aradıkları anlaşılmaktadır. Çünkü kendi aralarında herhangi bir devlet kurabilecek bir yetenekli lider çıkaramamışlardır.

424'lü yıllar geçildiğinde Tabgaç - Juan-juan savaşları hızla devam ediyordu. Kanglılar yine tarihî kaynaklarda yer almışlardır. Juan-juan'ları ağır bir bozguna uğratan Tabgaç hükümdarı ülkesine geri dönerken Kanglıların doğu boylarının bin li uzaklıktaki İ-ni-po isimli mevkide bulunduklarını duydu. Alınan bilgiye göre onların çok sayıda hayvanları vardı ve ayrıca çok kalabalık idiler. İmparator, onları An Yüan isimli bir generali vasıtasıyla baskına uğratıp, mallarını yağmalamak istedi. Onun bu fikrine durum tehlikeli olabilir diye bazı devlet adamları itiraz ettilerse de dinlemeyip gönderdi. Çinli kumandan öncelikle daha önce Tabgaç hakimiyetine giren Kanglı kabilelerini harekete geçirmişti. Üzerlerine büyük bir ordunun geldiğini gören İ-ni-po'daki Kanglılar, kendiliğinden teslim oldu. Verilen bilgiye göre yüzbinlerce Kanglı, Tabgaç hakimiyetine girdiği gibi bir milyondan fazla at, sığır ve koyun da ele geçirilmişti. Teslim olanlar hayvanlarıyla birlikte Gobi Çölünün bin li $(500 \mathrm{~km})$ güneyindeki bir yere yerleştirilmişlerdi. Kanglılar su ve meraları takip ederek hayvancılık yaptıklarından, ikamet ettirildikleri bölge onlara çok iyi gelmişti. Bu arada tarım ürünleri ekmeyi ve yemeği öğrendikleri vurgulanmaktadır. Tabii ürettikleri mallarından Çin sarayına vergi veriyorlardı. Neticede bölgelerinin verimliliği dolayısıyla Kanglıların hayvanlarının sayısı çok artmış; at, koyun ve sığır gibi hayvanlar ucuzlamıştı ${ }^{26}$. Burada bahsedilen İ-ni-po bölgesi Turfan'da olmalıdır ${ }^{27}$. Çin'e teslim olan Türklerin sayılarının birkaç yüz bin olması onların nüfusunun kuvveti hakkında bize fikir vermektedir.

25 Pei Shih 98, 3252; Wei Shu 103, s. 2292.

26 Pei Shih 98, 3273; Wei Shu 103, s. 2309.

27 Ögel, a.g.m., s. 820. 
428 yılında Juan-juan'ların hükümdarı Ta-tan, on binden fazla süvariyle Çin'in kuzey sınırlarını darmadağın etti. Çin'in sınırlarında yaşayan halklar yağmalanmış ve öldürülmüştü. Onların bu hücumlarını kendi tebaaları olan Kanglıları kullanmak suretiyle engelleyen Çinliler, arkalarından kendi kumandanları Kuang Ning'i göndermişlerdi. Fakat, bu kumandan Juan-juan'lara yetişemedi. Çünkü, Kanglılar, Juan-juan'ları ağır bir bozguna uğratmışlar, onları kuzeye çekilmek zorunda bırakmışlardı ${ }^{28}$.

430'da da Tabgaçlar, Juan-juan'lar üzerinde düzenledikleri büyük sefer ve kazandıkları zafer sırasında Kanglı'ların büyük yardımını gördüler. Adı geçen tarihte Tabgaç ordusu, Yenisey Irmağının kaynaklarına kadar uzanan uzun bir sefer düzenlemişti. Tabgaç ordusunun karşısında tutunamayan Juan-juan hükümdarı batıya doğru kaçtığında onları takip etmek işi Kanglılara kalmıştı. Önleri Kanglılar tarafından kesilince Juan-juan’lar geri dönmek zorunda kaldı. Üç yüz bin kişiden fazla Juan-juan, Tabgaçlara teslim oldu. Ayrıca bir milyondan fazla at onların eline geçmişti ${ }^{29}$.

430 yılındaki savaşlarda adlarının zikrinden sonra yaklaşık kırk bir sene yani 471 yılına kadar Kanglı adı kaynaklarda görülmemektedir. Bir başka ifade ile onlar herhangi bir olaya karışmamışlardı. Kao-tsung adı geçen tarihte Tabgaç imparatoru olduktan sonra onlar hakkında enteresan bir kayıtta “Kao-tsung zamanında (471-500) beş kabile Kanglı'ları toplanarak göğe kurban sundular. Birkaç on bin kişilik büyük bir kalabalığı toplantı yapıp at yarışları tertip ettiler. Bu hoş ve neşe veren bir adettir. En eski atalardan beri bile büyük bir bayram yapılmadı̆̆ını söylerler. Imparator da bizzat bayrama şeref verince herkes sevindi. " demektedir ${ }^{30}$.

Bundan sonra imparator Hsiao Wen, güneye düzenlediği bir sefere Kanglıların da katılmasını istedi. Ancak, onlar katılmadı. Üstelik Yüan-ho ailesinden Shu-che’yi kendilerine reis seçerek kuzeye ilerleyerek Çin sınırlarından çıkıp isyan ettiler. Chin-ling’e vardılar. Çin askeri valisi (tu-tu) Yü Wen-fu onların arkasından giderek yenilgiye uğrattı ve geri döndü. Devamında tekrar Çinliler tarafından mağlup edildiler. İkinci ordu tarafından da mağlup edilince Juan-juan'lardan diş destek aramayı düşündüler. Ancak, onlar da onu hakimiyetleri altına almak isteyince pişmanlık duyarak geri Çin'e geldi ve tâbi oldu. Kaynağın bildirdiğine göre bu sırada Kanglıların on iki boyu daha vard ${ }^{31}$. Her halde iki boy kuzey batıda bağımsız durumda bulunuyordu. Yüan-ho kabilesinin ya da ailesinin Kanglı boyları arasında önderlik yapacak konumda olduğu sonucu ortaya çıkmaktadır.

Kanglıların Çin'e giden grupları orada eriyip gitti. Ama, eski yurtlarında kalanlar, özellikle Juan-juan'ların baskısından kurtulanlar varlıklarını devam ettirebildiler.

28 Wei Shu, 91, 2130a.

29 Pei Shih 98, aynı yer.

30 Wei Shu 103, s. 2309; Pei Shih 98, 3273.

31 Pei Shih 98, s. 3273; Wei Shu 103, 2310. 
Kanglı'ların Fu-fu-lo adlı bir boyunun V. asrın ikinci yarısında kuvvetini artırıp siyasi bir birlik kurduğunu görmekteyiz. Önceden bu boy Juan-juan'lara itaat etmek zorunda birakıldı. Juan-juan'ların hükümdarı Tou-lun zamanında kendi içinde bu siyasi birlik parçalandı. Bunun üzerine A-fu-chih-lo, amcasının oğlu Ch'iung-ch'i kendi yanlarında yüz bin kişilik bir kütle ile birlikte Tabgaçlara bağland $1^{32}$.

Aslında Tou-lun, 479 yılında Tabgaçlara saldırdığında, A-fu-chih-lo buna karşı çıkmış ve kendine bağlı boylarla batıya doğru ilerlemişti. Akabinde batıda bir devlet kurdu.

Bu devlet bazı Kanglı gruplarının daha önce geldiği Ch'ien-pu bölgesinin kuzeyinde bir yerde kurulmuştu. Kaynakların bildirdiğine göre Hou-lou-pu-lo onların hükümdarlık unvanı idi. İmparator karşılığı kullanılmıştı. Çin dilinde anlamı Büyük Göğ̈̈n Oğlu idi. Amcasının oğlu Ch'iung-ch'i'nin unvanı vezir karşılığı olan Hou-pei idi. A-fu-chih-lo kuzeyde, güneyde Ch'iung-ch'i olmak üzere ülkelerini ikiye ayırmışlardı. Eskiden bağlı oldukları Tou-lun, onların üzerine birkaç defa saldırıp yendi ise de neticede A-fu-chih-lo tarafından mağlup edilerek, doğuya çekilmek zorunda birakıld $1^{33}$.

487 yılında Juan-juan hükümdarı Tou-lu, Çin’deki Wei devletine akın yapmak istediğinde Kanglı'lardan A-fu-chih-lo ona bu akının gereksiz olduğunu söyledi ise de Tou-lun dinlemedi. Buna kızan A-fu-chih-lo kendisine bağlı olanlarla birlikte batıya gitti ve bağımsızlığını ilan etti. İleri gelenleri ona "Ulu Gök'ün Oğlu” anlamına gelen Huo-lu-fu-lo unvanını verdiler. Ch'iung-ch'i ise veliaht idareci anlamına gelen Huo-pei adlı bir unvan aldı. Her iki Kanglı idarecisi barış içinde yaşamaya başladılar. A-fu-chih-lo kuzeyi, Huo-pei ise güneyi idare ediyordu. Juan-juan hükümdarı onları yenmek ve yeniden devletine bağlamak için geldi ise de A-fu-chih-lo tarafindan ağır bir bozguna uğratıldı. Neticede tuo-lun ülkesini doğuya taşımak zorunda kaldı.

Bundan sonra gittikçe kuvvetlendiği anlaşılan A-fu-chih-lo'nun liderliğindeki Fu-fu-lo Devleti ekonomik açıdan da kalkınmaya başladı. Üstelik dış diplomatik destek arayarak Juan-juan'ları ortadan kaldırmak niyetinde olan Kanglı hükümdarı 490 yılında Soğd asıllı Yüe-chu'yu Çin başkentine göndererek iki ok ve vergi takdim edip şöyle dedi: “Juanjuan'lar Çin imparatorlarının topraklarında çok yağmalar yaptılar. Biz onları tehdit ettik ise de dinlemediler. Bunun üzerine bizde onlara isyan ettik ve buraya geldik. Şimdi Juanjuan 'ları cezalandırmalıyı.."

Onların bütün iyi niyetine rağmen Tabgaç imparatoru Hsiao Wen, onlara inanmamış, durumu daha yakından anlamak için Yü-t’i adlı birini mukabil elçi olarak göndermişti. Arkasından yine Kanglı'ların idarecileri adı geçen Çin elçisi ile birlikte Pu-chie’yi gönderip

32 Pei Shih aynı yer; Wei Shu 103, aynı yer.

33 Pei Shih 98 ve Wei Shu 103, aynı yer. 
yine vergi sunmuşlardı. Maksatları Juan-juan'lara karşı ittifak yapmaktı. Bu defa ikna olan Çin imparatoru Yü-t'i'nin yanına Ch'ang-shang'ı da katarak Kanglı'lara bir defa daha gönderdi. Her ikisine de işlemeli pantolon ve ceketler ile yüz top kumaş verilmesini emretti ${ }^{34}$.

Onların Juan-juan'lardan kurtularak güçlenmeleri ipek yolu üzerindeki önemli bir merkez Turfan (Kao-ch'ang) üzerinde söz sahibi olmaları, Batı Türkistan’ın bir başka siyasi gücü Akhun'ların menfaatine dokunmuştu. Dolayısıyla Akhunlar, güneydeki Kanglı hükümdarı Ch'iung-ch'i’yi mağlup edip öldürdüler. Oğlu Mi-wu-t’u esir düştü. Dağılan boyların halkının bir kısmı Çin'e, diğer kısmı da Juan-juan'lara sığındı. Çin'e sığınanlar imparatorun emri ile Meng Wei tarafından Kao-p'ing-ch'eng'e yerleştirildiler (491-500) ${ }^{35}$.

Bundan sonra Çinlilerin de Turfan ve batıya giden ipek yolları üzerinde söz sahibi olmak isteği ön plana çıkıyordu. Fakat, Akhunlar o sırada çok güçlü olduklarından böyle bir şeye imkan yoktu.

Kuzeydeki Kanglı boylarının idarecisi A-fu-chih-lo'nun bölgesi ise iç çekişmeler yüzünden karışıklığa sürüklendi. Büyük oğlu babasının diğer karıları ile münasebette bulundu. Hatta babasını öldürmek için planlar kurduğunda onun tarafından öldürülerek ortadan kaldırılmıştı. Ancak, A-fu-chih-lo'nun zalimce idaresi yüzünden halk isyan edip onu öldürdü ve yerine devlet adamlarından Pa-li-yen'i reis seçtiler. Çin ile iyi ilişkiler tesis eden yeni Kanglı hükümdarı, Akhunlarla mücadele etmek zorunda kald1. Akhunlar, yeni hükümdarı tanımamışlar, daha önce esir aldıkları Mi-wu-t’u'yu Kanglı hükümdarı yapmak istemişlerdi. Halk, Pa-li-yen'i öldürüp Mi-wu-t'u'yu devletin başına geçirdi. Yeni hükümdar da Çin'e elçi gönderip vergi sundu. Sunulan hediyelerin miktarı bir külçe altın, bir külçe gümüş, altın çubuklar, yedi at ve on deve idi. Karşılığında Tabgaç imparatoru da Mu Jungt'an'ı Kanglılara gönderip çeşitli kumaşlardan 60 parça sunulmasını emretti.

Akhun-Çin ülkeleri arasındaki münasebetlerle sıkışan Kanglılar, kuzey doğudan gelen Juan-juan'larla, Barköl (P'u-lei)'ün doğusunda savaşmak zorunda kaldı. Juan-juan hükümdarı Fu-t'u, Mi-wu-t'u'yu bozguna uğrattı. Mağlup olan Kanglılar yüz li batıya kaçtı. Fu-t'u, ordusuyla Hami şehrine kadar ilerledi. Bu esnada Kao-ch'ang'lılar Çin'e göç ediyorlardı. Onları karşılamak için gelen Çinli general Meng Wei'i gören Fu-t'u korkup geri çekilmeye başladı. Onların geri çekilişini gören Mi-wu-t'u, Juan-juan'lara ani bir baskın yapıp, dağıttı. Hatta Fu-t'u'yu savaş meydanında (Barköl'ün kuzeyinde) öldürdü. Saçını keserek Çinli general Meng Wei'e gönderdi. Arkasından Tung-cheng beyi Yü-liang'1 gönderip beş tane iyi at, altın, gümüş, samur ve deri yolladı. Çinliler de ona kırmızı ipeklilerden on dört parça, çeşitli işlemelilerden altmış top hediye ettiler ${ }^{36}$.

34 Pei Shih, aynı yer; Wei Shu, aynı yer.

35 Pei Shih aynı yer; Wei Shu, aynı yer.

36 Pei Shih 98, s. 3273-3274; Wei Shu 103, s. 2310-2311. 
Mi-wu-t'u, Mo-ho Ch'ü-fen Wu-yin Ch'ih-ho-ch'en'1 göndererek kendi ülke mahsullerinden sundu ${ }^{37}$.

516 yılından (ya da o yıllarda) sonra Juan-juan'lar hükümdarları Ch'ou-nu önderliğinde, ona ağır bir darbe vurup savaş meydanında öldürdüler. Feci bir ölüm oldu. Onu yakalayıp başı yere gelecek şekilde iki bacağından atın eyerine bağladılar. Bu suretle başı yere sürtünerek öldürülmüş ve vernik sürülerek kafatasından içki tası yapılmıştır.

Onun ölümü üzerine Kanglı halkının hepsi kaçarak Akhunlara sığındı. Birkaç sene sonra Mi-wu-t'u'nun küçük kardeşi İ-fu'ya kendi ülkesine dönmesi için izin verildi. Bundan sonra Kanglı Devletinin başına o geçti. Çin’e elçi göndererek münasebette bulundu. Karşılığında Çinliler Yü K'ai'ı yollayarak, İ-fu'ya devlete açan kral ve batı denizi eyaletini Çin adına batı sınırlarını koruyan general unvanını sundular.

İ-fu'nun sayesinde Kanglı'lar bir kez daha Juan-juan'ları bozguna uğrattı. Bu sefer Juanjuan hükümdarı P'o-lo-men, Liang-chou'ya kaçtı.

522 yılında İ-fu, Çin’e elçi gönderip vergi sunarak, kırmızı boyalı, perdeli ve yastıklı, elle çekilen araba istedi. Kendisine buna ilave olarak beş tane mahmuz, kumaştan yelpaze, beş yeşil eyer, beş vernikli kapı, on davul boynuzu (tokmak) verilmesini arzu edince hepsi gönderildi.

Juan-juan'larla yaptığı ikinci savaşı kaybeden İ-fu, geri döndüğünde kendi küçük kardeşi Yüe-chü tarafindan öldürüldü. Bu sefer onun öldürdüğü hükümdarın oğlu Pi-shih, onu öldürüp kendi tahta geçti. 540 yılında o da Juan-juan'lara yenilmekten kurtulamadı. Tahta çıkan Yüe-chü, 536 yılında Juan-juan'lara tekrar yenilince Yüe-chü’nün oğlu Ch’ü-pin, kaçıp Çin'deki Wei Devletine sı̆̆ınmıştı. Doğu Wei Devletinin Hsien-wu adlı prensi imparatoruna rica ederek, onun ve etrafındakilerin Çin'e sığınmalarının kabulünü sağladı. Kanglı prensi ve kuzey güvenliğini kuran general unvanlarını alan Ch'ü-pin, az sonra hastalanıp öldü ${ }^{38}$.

Neticede Kanglı adı Ting-ling'in yerini aldıktan sonra 536 yılına kadar varlığını sürdürdü. Onların yerine bahsettiğimiz tarihlerde Töles ana boy grup adı ortaya çıktı. Töles boy grubu kaynaklara göre Moğolistan'daki Tola Irmağından Kafkas Dağlarının kuzeyine kadar geniş alanda dağınık yaşıyorlardı. Kanglılar, Ting-ling'lerden aldıkları mirası Töleslere aktardılar. Böylece varlığından haberdar olduğumuz Töleslerden zamanımız Türk Dünyasını oluşturan boyların alt yapısı meydana geldi. Bu duruma göre Kanglıların, Ting-lingler ile Tölesler arasında köprü vazifesini gördüğünü anlamak mümkündür. 11. yüzyılda Aral Gölünün kuzey ve doğu taraflarında Kıpçak boyları arasında karşımıza çıkan Kanglı boyu daha sonra başta Kazak topluluğu arasında olmak üzere günümüze kadar ulaşma başarısını göstermiştir.

37 not 27 ve de Enoki, aynı eser, s. 153.

38 Wei Shu 103, s. 2311-2312; Pei Shih 98, 3275. 
Hakem Değerlendirmesi: Dış bağımsız.

Çıkar Çatışması: Yazar çıkar çatışması bildirmemiştir.

Finansal Destek: Yazar bu çalıșma için finansal destek almadığını beyan etmiștir.

Peer-review: Externally peer-reviewed.

Conflict of Interest: The author has no conflict of interest to declare.

Grant Support: The author declared that this study has received no financial support.

\section{Kaynakça/References}

\section{Kaynak Eserler}

Wei Shu魏書 (Wei Shou/636) (Ting-wen shu-chü yayınevi baskıs1, Tai-pei 1987)

Chou Shu周書 (Ling-hu Te-feng/629) (Ting-wen shu-chü yayınevi baskısı, Tai-pei 1987)

Pei Shih 99 北史 (Li Te-lin/636) (Ting-wen shu-chü yayınevi baskısı, Tai-pei 1987)

Suei Shu隋書 (Wei Cheng/636), (Ting-wen shu-chü yayınevi baskısı, Tai-pei 1987)

Chiou T'ang Shu舊唐書 (Liou Hsü/945) (Ting-wen shu-chü yayınevi bask1s1, Tai-pei 1985)

Hsin T’ang Shu新唐書 (Ou Yang-hsiou/ 1060) (Ting-wen shu-chü yayınevi baskısı, Tai-pei 1985)

T’ung Tien通典 (Tu Yu/805) (Shang-wu bask1s1, Shang-hai 1935)

Ts'u-fu Yüan-kuei册府元亀 (Wang Ch'in-jo ve Yang İ/ 1005-1013) (Chung-hua Shu-chü yayınevi baskıs1, T’ai-pei 1981)

Wen-hsien T'ung-k'ao文獻通考 (Ma Tuan-lin/ 1254), (Shang-wu bask1s1, Shang-hai 1935)

\section{Telif Eserler}

Enoki, K., “On the Nationality of the Ephtalites”, Studia Asiatica, Tokyo 1998, s. 140-143.

Esin, Emel, İslâmiyetten Önce Türk Kültür Tarihi, İstanbul 1978.

Kuo-chien, Fan, Pei Wei Yü Juan-juan Yen-chiou, Tai-pei 1988.

Ögel, Bahaeddin, “İlk Töles Boyları”, Belleten, XII/48 (1948), 795-833.

Ögel, Bahaeddin, Türk Mitolojisi, Ankara 1993.

Salgarulı, K., Dunhu-Kaoçı, Almatı 1999.

Taşağıl, Ahmet, Çin Kaynaklarına Göre Türk Boyları, Ankara 2004.

Türkeli, Cevat, Çin Kaynaklarına Göre Hunların Ataları, İstanbul Üniversitesi Sosyal Bilimler Enstitüsü, Yayınlanmamış Doktora Tezi, İstanbul 1991. 